\title{
Implementasi Unit Testing Menggunakan Metode Test-First Development
}

\author{
Muhamamd Agung Rizkyana ${ }^{1}$, Yunanto, Yoga, Caca Arif Herdian, Ahmad Ainul Yaqin R \\ Magister Sistem Informasi, STMIK LIKMI, Bandung \\ Jl. Ir.H. Juanda No. 96, Lebakgede, Kec. Coblong, Kota Bandung, 0222502121 \\ agung.rizky@gmail.com
}

Diterima : 11 Desember 2020. Disetujui : 19 Maret 2021. Dipublikasikan : 30 Mei 2021.

\begin{abstract}
Today we are faced with a disruption era that brought some challenges for any business field, especially the software development field. Software development should be adaptive to those challenges. One of the most used and implemented for today in software development lifecycle was Agile. Agile Methodology can push out the software to be released. Meanwhile, the release velocity was not enough to keep the software accepted and used by users. The quality of the software was necessary because the alignment belongs to user needs showing those qualities. One of the methods in Agile that assuring the quality was Test-Driven Development (TDD). TDD has various techniques. This research used TestFirst Development (TFD). TFD technique used for guidance unit testing of data service application with REST API architecture. The objective was to show TDD implementation that aligns with the concept and theory for the case study.
\end{abstract}

Keywords: agile, test-driven development, test-first development, unit tests, rest api

Abstrak - Tuntutan untuk dapat terus bersaing dan berkualitas di era distriupsi saat ini menjadi tantangan khususnya pengembangan perangkat lunak. Untuk menjawab tantangan tersebut salah satu metodologi pengembangan yang berkembang dan banyak diimplementasikan adalah Agile. Metodologi Agile memungkinkan perangkat lunak untuk dapat segera diluncurkan. Namun, kecapatan saja tidak cukup untuk dapat menjaga sebuah perangkat lunak atau aplikasi dapat diterima dengan baik oleh pengguna. Kualitas dari perangkat lunak adalah hal penting, karena kesesuaian dengan kebutuhan pengguna menunjukan kualitas perangkat lunak tersebut sehingga timbul keterikatan antara pengguna dan aplikasi. Salah satu metode pada Agile yang menjamin hal tersebut adalah Test-Driven Development (TDD). TDD mempunyai beberapa teknik dalam praktisnya, pada penelitian ini menggunakan Test-First Development (TFD). Teknik TFD digunakan untuk menjadi panduan pengujian unit (Unit Testing) pada aplikasi penyedia data dengan arsitektur REST API. Tujuan dari penelitian ini adalah menunjukan langkah - langkah sistematis implementasi TDD sesuai konsep dan teori pada suatu studi kasus.

Kata kunci: agile, test-driven development, test-first development, unit tests, rest api

\section{PENDAHULUAN}

Siklus pengembangan perangkat lunak telah mengalami perkembangan seiring dengan kompleksitas dan distrupsi saat ini. Kebutuhan untuk dapat segera rilis agar dapat terus bersaing dan eksis. Namun, jika hanya sekedar rilis tanpa mempertimbangkan kualitas akan mengurangi engagement pengguna, manfaat dari perangkat lunak atau bahkan kualitas pengembangan perangkat lunak itu sendiri. Salah satu siklus pengembangan yang sedang populer saat ini adalah Agile. Metode Agile mempunyai prinsip pengembangan yang dinamakan Agile Manifesto. Prinsip tersebut antara lain, terbuka akan perubahan (Welcoming Changes), rutin mengirimkan kemajuan produk (Delivering Frequent Working Product Iterations), dan mengizinkan setiap anggota tim untuk mengelola secara mandiri (allowing teams fo self-organize) [1].

Agile tidak hanya sebagai proses atau metodologi, juga berisi sekelompok praktis, nilai dan prinsip. Keunggulan metode Agile dibandingkan dengan pengembangan perangkat lunak antara lain [2]:

1. Perubahan dinamis dari kebutuhan sistem dapat langsung diterapkan.

2. Pelanggan dilibatkan dalam setiap proses pengembangan.

3. Komunikasi antara pengembangan dan pelanggan sangat intensif.

4. Pelanggan tidak perlu menunggu hingga projek selesai.

5. Organisasi dapat menjamin bahwa produk dapat diterima oleh pelanggan setelah projek selesai.

6. Pengembang dapat dengan mudah melakukan ubahan sesuai permintaan pelanggan.

7. Hampir $100 \%$ pelanggan merasa puas dengan metode Agile.

Sementara itu, dalam praktis Agile, terdapat berbagai metode, salah satunya adalah Test-Driven Development.

Metode Test-Driven Development (TDD) membantu validasi dan verifikasi kualitas perangkat 
lunak dengan kebutuhan pengguna. Terdapat beberapa teknik dalam TDD, salah satunya adalah Test-First Development (TFD) merupakan teknik membuat kode pengujian sebelum kode tersebut menjadi suatu fungsi yang utuh. Kode pengujian tersebut berdasarkan kepada kebutuhan sistem. Pengembang aplikasi agar dituntut untuk dapat membuat kode pengujian berdasarkan kebutuhan tersebut. Pengembang dapat mendekomposisi setiap kebutuhan sistem menjadi bagian-bagian kecil pengujian (unit testing). Bagian tersebut dapat berupa fungsi, metod atau class.

Penelitian ini merupakan perkembangan dari penelitian-penelitian sebelumnya. Adapun beberapa penelitian yang menjadi inspirasi dari penelitian ini terdapat pada tabel 1. Karya ilmiah tersebut menjadi acuan untuk uraian konsep dan teori Test-Driven Development, proses pada TDD, perbandingan TDD dengan BDD, dan implementasi TDD.

\section{TABEL I. PENELITIAN TERKAIT}

\begin{tabular}{ccc} 
Judul & Tahun & Penulis \\
\hline Assessing the & 2019 & $\begin{array}{c}\text { Avishek Sharma } \\
\text { Dookhun, } \\
\text { Effectiveness of Test- } \\
\text { Driven Development and }\end{array}$ \\
Behavior-Driven & & Nagowah \\
Development in an & & \\
Industry Setting & & \\
\hline Comparative Study of & 2019 & Myint Myint \\
Test-Driven & & Moe \\
Development, Behavior- & & \\
Driven Development, and & & \\
Acceptance Test-Driven & & \\
Development & & \\
\hline Implementasi Test- & 2018 & Jamalludin, \\
Driven Development & & Herman \\
Pada Pengembangan & & Yuliansyah, Sri \\
Aplikasi Android untuk & & Winiati, Imam \\
Mahasiswa Universitas & & Riadi \\
Ahmad Dahlan & \\
\hline
\end{tabular}

Penelitian ini bertujuan untuk menunjukan langkah - langkah implementasi TDD menggunakan teknik Test First Development dan Unit Testing pada aplikasi backend penyedia data pengelolaan manajemen laboratorium kalibrasi. Modul dari aplikasi yang menjadi bagian penelitian ini adalah modul pengelolaan order dan autentikasi pengguna. Aplikasi menggunakan arsitektur REST sebagai teknik untuk mendistribusikan data.

Konsep makalah ini terdiri dari beberapa bagian antara lain Pendahuluan, Metode Penelitian, Hasil dan Pembahasan, Kesimpulan. Pendahuluan mengulas tentang siklus pengembangan perangkat lunak, uraian singkat TDD, penelitian terkait dan konsep makalah.Metode penelitian mengulas tentang literasi dari TDD, Unit Testing, REST API Service, Refactoring, dan Studi kasus. Hasil dan pembahasan mengulas tentang implementasi TDD pada studi kasus. Kesimpulan mengulas tentang intisari dari makalah ini.

\section{METODE PENELITIAN}

Penelitian ini menggunakan metode studi literatur dan eksperimen. Studi literatur berfokus pada topik Test-Driven Development (TDD), Unit testing dan REST API service. Eksperimen berfokus pada praktis - praktis TDD yaitu dengan teknik Test-First Development (TFD) dan refactoring.

\section{A. Test-Driven Development}

Test-Driven Development (TDD) menurut Ida Bagus, TDD adalah metode pengujian yang mewajibkan setiap pengembang untuk membuat rincian tujuan daripada pengujian sebelum membuat kode. Setelah pengujian dibuat, pengembang harus membuat kode yang memenuhi persyaratan uji hingga kode tersebut tidak mempunyai kesalahan atau kegagalan saat dibuat [13]. TDD memberikan kepastian terhadap peningkatan kualitas dan produktivitas, di tunjang dengan perkembangan kakas pengujian sebagai dukungan [7]. TDD merupakan salah satu teknik dalam pengembangan perangkat lunak yang menggabungkan rancangan program dan pengujiannya dalam satu iterasi kecil (micro-iterations). TDD juga memberikan kepercayaan diri terhadap setiap pengembang serta meningkatkan jangkauan uji (test coverage) pada sistem [3].

Secara umum, implementasi TDD menggunakan terminologi siklus red-greenrefactor. Red menunjukan pengujian kegagalan terhadap kode. Green menunjukan kode perlu untu diubah dan diuji keberhasilannya. Refactor menunjukan perubahan atau perbaikan kode [3]. Efektifitas TDD dalam peningkatan kualitas pengembangan dibuktikan dari beberapa penelitian yang dilakukan oleh perusahaan teknologi informasi skala global, antara lain Microsoft, IBM dan Ericsson.

Berdasarkan penelitian yang dilakukan oleh Microsoft, penerapan TDD pada suatu projek telah meningkatkan kualitas kode hampir 2 (dua) kali lipat namun menggunakan waktu $15 \%$ lebih banyak untuk menulis kode pengujian. Sementara itu, IBM menyatakan bahwa penurunan $40 \%$ dari laporan kegagalan tanpa mempengaruhi produktivitas tim. Kemudian, Ericson dalam suatu studi kasus menunjukan peningkatan kualitas kode sebagai dampak dari peningkatan produktivitas tim sebesar $16 \%$ [3].

TDD memiliki sudut pandang dari pengembang (developer). Pengembang menggunakan requirement sistem kemudian diubah menjadi kode uji unit. Sementara itu, terdapat sudut 
pandang lain dengan proses pengujian yang relatif sama. Behavior Driven-Development adalah alternatif penerapan TDD dengan penambahan sudut pandang berdasarkan skenario bisnis. BDD melibatkan developer, pengguna dan tester untuk validasi dan verifikasi kualitas perangkat lunak. Sebagai gambaran, pada gambar 1 ditunjukan pengujian dengan pendekatan TDD dan pada gambar 2 ditunjukan pengujian dengan pendekatan BDD [21].



Gambar 1. Alur kerja pada Pendekatan TDD [21]

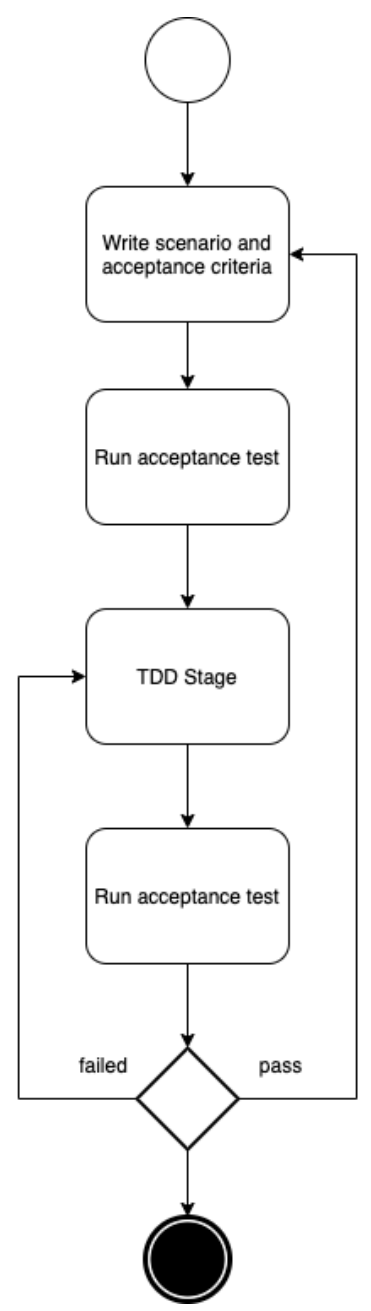

Gambar 2. Alur kerja pada Pendekatan BDD [21]

Praktek TDD bersifat iteratif, di setiap iterasi pada umumnya melalui beberapa tahapan sebagai berikut [5]:

1. Membuat kode pengujian untuk fungsionalitas yang akan dimasukan ke dalam sistem.

2. Jalankan semua kode uji dan perhatikan setiap kegagalan

3. Buat kode perbaikan terhadap setiap pengujian yang gagal

4. Jalankan semua kode uji dan perhatikan setiap pengujian yang lolos.

5. Lakukan refactor kode untuk meningkatkan kualitas.

Setiap pengembang yang menerapkan TDD, harus memelihara rangkaian kode-kode pengujian dan hanya mengaplikasikan kode yang sudah lulus uji. Setiap kode uji adalah executable spesication yang artinya dapat dijalankan melalui perintahperintah program. Sementara itu, kode uji tersebut akan membantu pengembang untuk memahami alasan mengapa fitur tersebut harus dibuat, menunjukan bagaimana cara fungsi tersebut di panggil atau apa hasil yang ingin dicapai [5]. 
Proses-proses yang terdapat pada TDD dapat dibagi menjadi 3 bagian utama antara lain: granularity, uniformity dan sequencing. Granularity dan uniformity berhubungan dengan proses iteratif. Sementara itu, sequencing berhubungan dengan urutan setiap proses di dalam siklus iterasi [6]. Dalam siklus iterasi, TDD berfokus pada sudut pandang "inside-out" yang bermakna bahwa setiap pengujian dibuat dari sudut pandang pengembang. Pengembang memaknai setiap kebutuhan sistem menjadi kasus uji (test-case). Selanjutnya, pengembang membuat kode uji terhadap kasus uji tersebut yang harus di pastikan bisa lolos. TDD memaksa pengembang berfokus kepada kebutuhan sistem [11].

Fokus tersebut membuat suatu perangkat lunak dianggap berkualitas. Ukuran kualitas tersebut adalah bekerja sesuai apa yang diinginkan pengguna dan proses bisnisnya. Pada TDD, diterapkan pengujian unit (unit testing) yang berfungsi untuk menjaga pengembangan perangkat lunak tetap sesuai dengan kebutuhan [12]. Selain itu, tujuan akhir dari TDD adalah membentuk kode yang lebih jelas, sederhana dan bug-free [11].

Kemudian terdapat tantangan dalam penerapan TDD. Sebagai contoh, pengembang mengalami kesulitan untuk membuat kode pengujian terhadap suatu fungsi tapi sebenarnya tidak ada yang perlu di uji. Adapun Langkah-langkah yang bisa lakukan apabila mengalami hal tersebut, antara lain

1. Tentukan input dan output dari fitur spesifik.

2. Tentukan parameter untuk fungsi pengujian.

3. Fokus kepada 1 aspek pengujian.

4. Implementasikan fungsi pengujian dengan sudut pandang behavior bukan bagaimana menerapkan kode tersebut.

5. Terapkan kode yang sudah lolos uji satu per satu.

TDD memberikan dampak yang signifikan pada produktivitas pekerjaan pengembangan perangkat lunak. Sebuah penelitian yang dilakukan oleh Vojislav Misic pada tahun 2018 tentang efektivitas TDD terhadap kualitas dan produktivitas, menunjukan bahwa TDD menambahkan sebuah peningkatan kecil pada kualitas tetapi tidak begitu menyakinkan pada produktivitas. Karena, terdapat beberapa perbedaan hasil ditinjau dari konteks dimana TDD tersebut diterapkan. Konteks tersebut terdiri dari perbandingan tempat diterapkan dan siklus pengembangannya. Perbandingan pertama adalah Akademik dengan Industri. Kemudian, perbandingan kedua adalah siklus waterfall dengan ITL (Iterative Test-Last) [4].

\section{B. Unit Testing}

Dalam prateknya, TDD melakukan pengujian yang terisolasi dan berfokus pada kebutuhan serta proses bisnis. Aspek tersebut adalah unit pengujian (unit testing). Pengujian unit merupakan bagian dari level pengujian lainnya. Menurut Mike Cohn dalam buku Succeeding with Agile, dikemukan tentang Testing Pyramid.

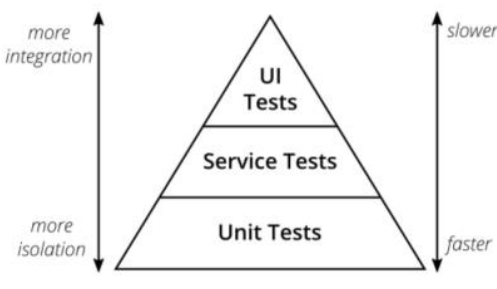

Gambar 3. Testing Pyramid [17]

Pada gambar 3, ditunjukan tentang layer pengujian. Secara urutan, dari atas ke bawah menunjukan semakin terisolasi kepada bagian terkecil (unit). Dari bawah ke atas secara waktu pengujian semakin lama. Testing pyramid terdiri dari UI Tests, Service Tests dan Unit Tests. UI Tests dilakukan proses pengujian langsung oleh pengguna. Service Tests dilakukan proses pengujian untuk memastikan integrasi antara fungsional sistem. Unit Tests dilakukan proses pengujian terhadap fungsional sistem [17].

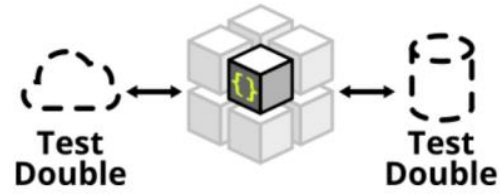

Gambar 4. Unit Tests

Definisi unit tests apabila dihubungkan dengan bahasa dan paradigma pemrograman, setidaknya akan mempunyai perbedaan definisi. Pada pemrograman berbasis fungsi (functional programming), unit adalah suatu fungsi yang dipanggil dan disertai dengan parameter untuk selanjutnya diuji kesesuaian nilai yang dikembalikan (return value). Sedangkan pada pemrograman berbasis objek, unit dapat dimaknai sebagai method atau keseluruhan class [17]. Menurut Vladimir, definisi dari unit test adalah suatu pengujian yang di otomatisasi untuk melakukan verifikasi terhadap bagian terkecil (unit) dari kode, dilakukan secara cepat dan terisolasi [18]. 




Gambar 5. Struktur Unit Test

Sebuah unit test mempunyai struktur yang membentuknya. Mungkin terdapat beberapa perbedaan dari cara penggunaannya tergantung bahasa pemrograman. Pada penelitian ini menggunakan bahasa pemrograman Typescript. Gambar 5 menunjukan struktur dari unit test update status order. Struktur unit test dapat dibentuk melalui pola AAA yaitu Arrange, Act dan Assert.

Pada arrange, dipersiapkan semua data yang dibutuhkan pada fungsi sebagai parameter. Pada act, dilakukan pemanggilan fungsi kemudian di lemparkan (pass) variabel dari data ke dalam fungsi tersebut. Pada assert, dilakukan verifikasi dari output fungsi tersebut. Pola Arrange, Act dan Assert sebaiknya dihindari untuk terjadinya duplikasi di setiap komponennya. Hal ini untuk tetap menjaga sebuah unit test tetap sederhana, cepat dan mudah untuk di pahami [18].

Unit testing bergantung kepada bahasa pemrogram yang digunakan. Pada penelitian ini menggunakan Typescript. Kemudian, unit testing agar lebih efektif menggunakan library pendukung, pada penelitian ini menggunakan JEST. Untuk dapat menggunakan JEST pastikan terlebih dahulu lingkungan pengembangan sudah terinstall NodeJS. Proses pengujian unit akan menggunakan perintah dari command-line. Pada konfigurasi awal, JEST akan mengenali suatu berkas yang merupakan unit pengujian dengan pola [nama-unit].test.[ext]. Jika pada bahasa pemrograman Typescript, maka pola nama berkas yang digunakan adalah order.test.ts.

\section{REST API Service}

REST API Service adalah salah satu teknik dan arsitektur dalam web service. Webservice merupakan sistem perangkat lunak yang didesain untuk dapat dioperasikan dari mesin ke mesin melalui jaringan. Secara umum, arsitektur web service terdiri dari penyedia, konsumen dan pendaftar. Melalui web service dimungkinkan untuk menghubungkan secara dinamis baik perangkat keras, maupun perangkat lunak dalam suatu jaringan [16].

REST API sendiri merupakan arsitektur distribusi data dan proses antara aplikasi dan service melalui jaringan internet dengan protokol HTTP. REST API diakses dan dikenali melalui alamat URL yang unik serta metod yang menyertainya seperti GET, POST, PUT, atau DELETE [16]. REST adalah singkatan dari Representational State Transfer. REST API mempunyai kebebasan untuk format data yang diterapkan padanya seperti JSON, XML, atau TEXT [15].

\section{Test-First Development}

Penelitian ini menggunakan salah satu teknik dari Test-Driven Development (TDD) yaitu TestFirst Development (TFD). Pada gambar 6, ditampilkan alur pengembangan pengujian aplikasi. Pada tahapan pertama dibuat terlebih dahulu skenario pengujian dan kasus uji (test case).

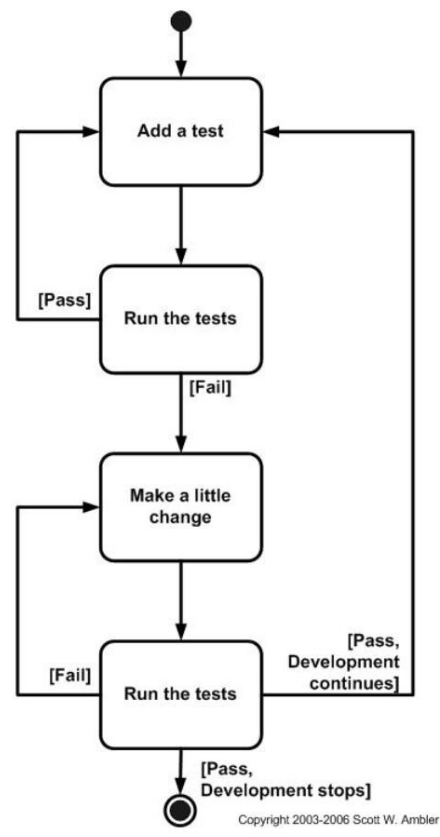

Gambar 6. Test-First Development [19]

Test case dijalankan untk menguji kegagalannya terlebih dahulu. Apabila sudah dapat diketahui kegagalannya maka dianggap benar (pass). Selanjutnya, dilakukan refactoring pada kode agar proses dioptimalisasi dan kode lebih mudah dibaca. Kemudian, kode yang sudah di refactor, dilakukan pengujian kembali dengan harapan uji berhasil. Apabila terjadi kegagalan maka dilakukan tinjauan ulang terhadap kode untuk selanjutnya di perbaiki dan dilanjutkan kembali hingga pengujian dianggap berhasil. Setelah pengujian berhasil, maka kode dibuat dengan lebih tepat secara fungsional dan pola design (Design Pattern) [19].

\section{E. Refactoring}

Teknik TFD pada umumnya akan menghasilkan kode yang tidak rapih. Oleh karena itu, proses refactoring menjadi perlu untuk dilakukan. Refactoring adalah proses untuk membuat kode lebih mudah di kelola (Maintain), 
sesuai dengan pola design (Design Pattern) dan dapat dipahami oleh pengembang lain [12].

Menurut Martin Fowler, definisi dari refactoring adalah segala hal tentang penerapan ubahan kecil pada tiap tiap bagian kode untuk kemudian menjadi ubahan yang cukup besar dengan menggabungkan setiap ubahan kecil tersebut pada suatu urutan yang sistematis [17].

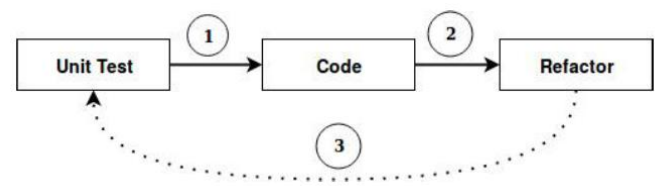

Gambar 7. Proses refactoring [12]

Pada gambar 7, ditampilkan alur proses daripada refactoring. Pertama, pengembang membuat terlebih dahulu unit uji (unit test). Unit uji dapat berupa alur fungsional yang sederhana dan sebaiknya mempunyai satu assertion. Assertion adalah fungsi dari modul pengujian untuk membantu kepastian hasil dengan ekspektasi pada skenario pengujian. Selanjutnya, pengembang membuat kode untuk unit uji tersebut. Apabila sudah sesuai ekspektasi atas hasil uji tersebut, dilanjutkan dengan refactoring kode.

\section{F. Sistem Informasi Pelayanan Laboratorium Kalibrasi}

Sistem Infomrasi Pelayanan Laboratorim Kalibrasi dirancang untuk pengelolaan permintaan kalibrasi alat berdasarkan lingkup yang sudah ditentukan. Sistem informasi ini bernama Kallon. Kallon mempunyai fitur yang terdiri dari:

1. Pengelolaan order

2. Pengelolaan penjualan

3. Pengelolaan penagihan

Saat ini sistem informasi tersebut masih dalam pengembangan dan menerapkan metodologi agile dengan teknik prototyping dan TDD. Fitur yang sudah dapat digunakan adalah pengelolaan order. Arsitektur yang digunakan adalah backendfor-frontend (BFF), dengan dukungan REST API.

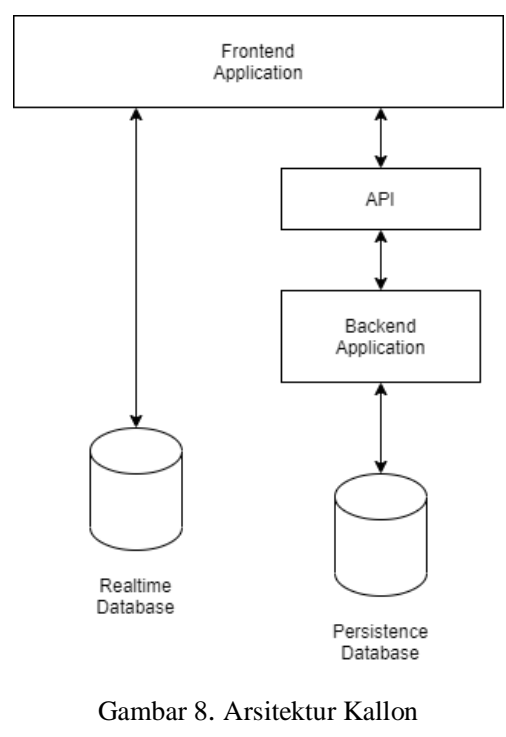

Pada gambar 8 ditunjukan arsitektur Kallon. Kallon terdiri dari aplikasi frontend, API, aplikasi backend dan dua jenis database yaitu realtime dan persistence. Realtime database menggunakan Firebase dan persistence menggunakan MongoDB. Aplikasi frontend dibangun menggunakan Typescript dengan framework ReactJS. Untuk aplikasi backend dan API dibangun menggunakan Typescript dengan framework ExpressJS Gambar 9 - 12 menunjukan tampilan dari aplikasi Kallon untuk pengelolaan order kalibrasi.



Gambar 9. Daftar Order Kalibras

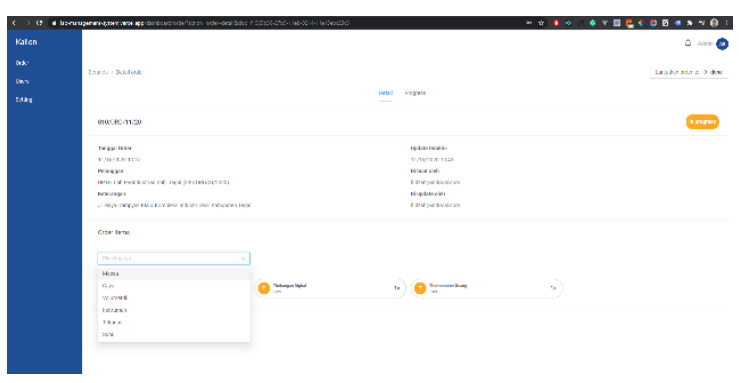

Gambar 10. Detail Order Kalibrasi 


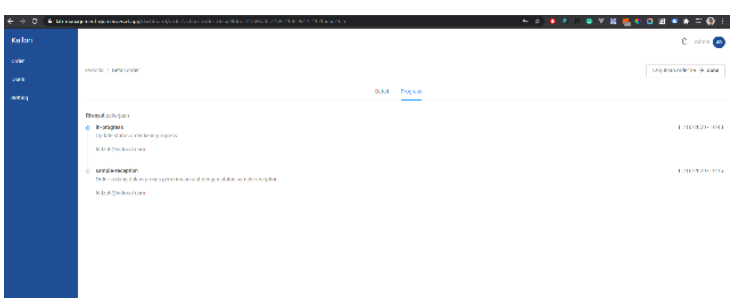

Gambar 11. Kemajuan Pelayanan Order Kalibrasi

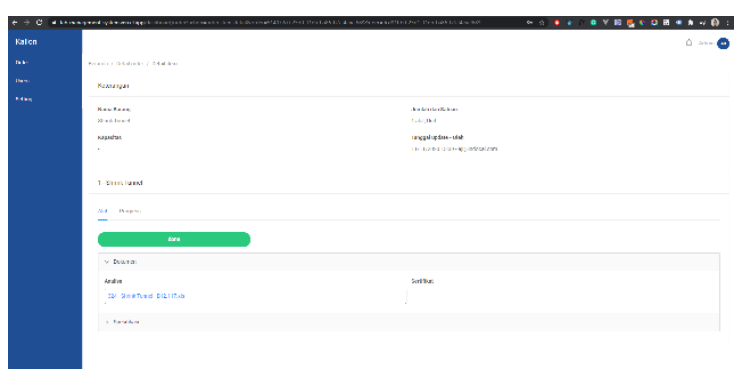

Gambar 12. Detail Alat pada Suatu Order Kalibrasi

\section{HASIL DAN PEMBAHASAN}

Hasil dari penelitian ini adalah menyajikan Langkah-langkah sistematis sesuai dengan konsep TDD serta implementasi unit testing. Implementasi tersebut terdapat pada layanan REST API melalui protokol HTTPS untuk mengelola data berformat JSON. REST API digunakan pada layanan pada produk Kallon. Kallon adalah perangkat lunak berbasis web yang mengelola pelayanan kalibrasi. Setiap iterasi TDD, menerapakan pengujian unit.

\section{A. Skenario Pengujian Unit}

Pengujian unit pada penelitian ini berfokus pada endpoint order dan autentikasi. Endpoint order mempunyai use-case buat order, update order, pencarian order, dan daftar order. Endpoint authentikasi mempunyai use-case buat akses token dan validasi token. Skenario pengujian terdiri dari test case, expected failed dan expected success. Pada Tabel 2 terdapat skenario pengujian unit pada endpoint order sedangkan pada tabel 3 terdapat skenario pengujian unit untuk endpoint autentikasi.

TABEL II. SKENARIO PENGUJIAN UNIT ORDER

\begin{tabular}{|c|c|c|c|}
\hline Test ID & Test Case & $\begin{array}{l}\text { Expected } \\
\text { Failed }\end{array}$ & $\begin{array}{l}\text { Expected } \\
\text { Success }\end{array}$ \\
\hline $\begin{array}{c}\text { T-ORD- } \\
001\end{array}$ & $\begin{array}{l}\text { Update } \\
\text { status } \\
\text { order }\end{array}$ & $\begin{array}{c}\text { Tidak bisa } \\
\text { update order } \\
\text { karena } \\
\text { OrderID tidak } \\
\text { ditemukan }\end{array}$ & $\begin{array}{c}\text { Berhasil update } \\
\text { order dengan } \\
\text { OrderID } \\
\text { 001/ORD/10/20 }\end{array}$ \\
\hline $\begin{array}{c}\text { T-ORD- } \\
002\end{array}$ & $\begin{array}{l}\text { Create } \\
\text { order }\end{array}$ & $\begin{array}{c}\text { Tidak bisa } \\
\text { create order } \\
\text { karena } \\
\text { OrderID sudah } \\
\text { ada }\end{array}$ & $\begin{array}{c}\text { Berhasil create } \\
\text { order }\end{array}$ \\
\hline $\begin{array}{l}\text { T-ORD- } \\
003\end{array}$ & $\begin{array}{l}\text { List order } \\
\quad \text { with } \\
\text { parameter }\end{array}$ & $\begin{array}{l}\text { Tidak bisa } \\
\text { mendapatkan } \\
\text { list order } \\
\text { karena }\end{array}$ & $\begin{array}{c}\text { Berhasil } \\
\text { mendapatkan } \\
\text { list order }\end{array}$ \\
\hline
\end{tabular}

\begin{tabular}{|c|c|c|c|}
\hline Test ID & Test Case & $\begin{array}{c}\text { Expected } \\
\text { Failed }\end{array}$ & $\begin{array}{c}\text { Expected } \\
\text { Success }\end{array}$ \\
\hline & $\begin{array}{c}\text { Limit and } \\
\text { Page }\end{array}$ & $\begin{array}{c}\text { kesalahan } \\
\text { parameter limit } \\
\text { dan page }\end{array}$ & \\
\hline $\begin{array}{c}\text { T-ORD- } \\
004\end{array}$ & $\begin{array}{l}\text { Generate } \\
\text { Order ID }\end{array}$ & $\begin{array}{c}\text { Nomor order } \\
\text { tidak sesuai } \\
\text { dengan format } \\
\text { yang } \\
\text { ditentukan }\end{array}$ & $\begin{array}{c}\text { Berhasil } \\
\text { membuat } \\
\text { nomor order } \\
\text { sesuai dengan } \\
\text { format yang } \\
\text { ditentukan }\end{array}$ \\
\hline $\begin{array}{c}\text { T-ORD- } \\
005\end{array}$ & $\begin{array}{c}\text { Get single } \\
\text { order by } \\
\text { Order ID }\end{array}$ & $\begin{array}{c}\text { Tidak bisa } \\
\text { mendapatkan } \\
\text { order }\end{array}$ & $\begin{array}{c}\text { Berhasil } \\
\text { mendapatkan } \\
\text { order }\end{array}$ \\
\hline
\end{tabular}

TABEL III. SKENARIO PENGUJIAN UNIT AUTENTIKASI

\begin{tabular}{cccc} 
Test ID & Test Case & $\begin{array}{c}\text { Expected } \\
\text { Failed }\end{array}$ & $\begin{array}{c}\text { Expected } \\
\text { Success }\end{array}$ \\
\hline T- & Create basic auth & Gagal & Berhasil \\
AUTH- & token & $\begin{array}{c}\text { membuat } \\
\text { token }\end{array}$ & $\begin{array}{c}\text { membuat } \\
\text { token }\end{array}$ \\
001 & & Gagal & Berhasil \\
T- & Validate basic & validasi & validasi \\
AUTH- & auth token & token & token
\end{tabular}

\section{B. Implementasi Pengujian Unit}

Service REST API ini dikembangkan menggunakan bahasa pemrograman Typescript. Untuk pengujian unit menggunakan kakas dari JEST. Konfigurasi Jest untuk dapat melakukan pengujian unit pada projek service REST API ini terdapat pada package.json. Gambar 13 menunjukan konfigurasi project REST API yang sudah tersedia JEST.

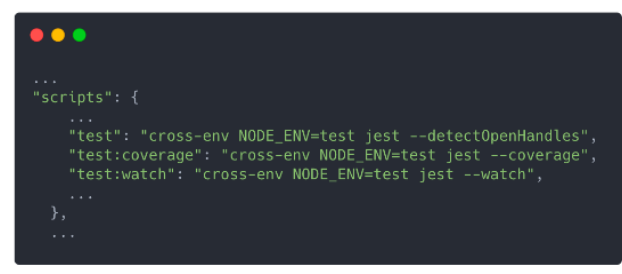

Gambar 13. Konfigurasi JEST

Struktur unit testing menggunakan pendekatan Arrange, Act, Assert. Pada arrange data dipersiapkan, act dilakukan pemanggilan fungsi kemudian pada assert di validasi ekspektasi hasilnya. Gambar 14 menunjukan code dasar untuk membuat unit testing. Gambar 15 menunjukan perintah untuk menjalankan unit testing. 


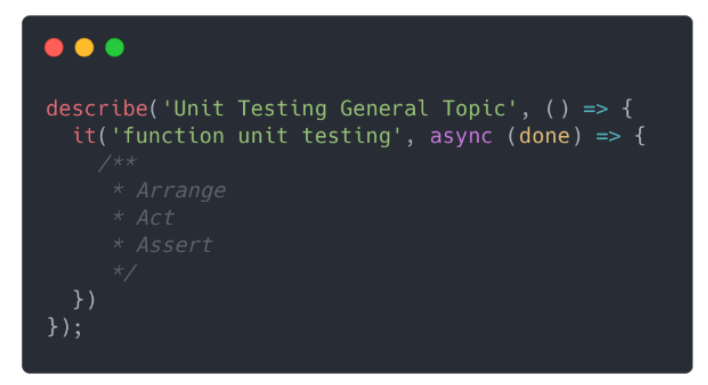

Gambar 14. Code Dasar Pengujian Unit

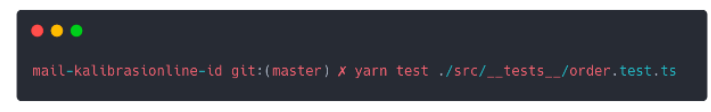

Gambar 15. Perintah untuk Melakukan Pengujian Unit

\section{Hasil Pengujian Unit}

Pengujian unit menggunakan library dari node package manager (NPM) dengan nama JEST. Sebelum dilakukan pengujian, JEST perlu untuk dikonfigurasi terhadap projek ini. Tahapan konfigurasi dilakukan dengan cara sebagai berikut:

1. Buka terminal melalui text editor Visual Studio Code, dengan perintah seperti pada gambar 16.

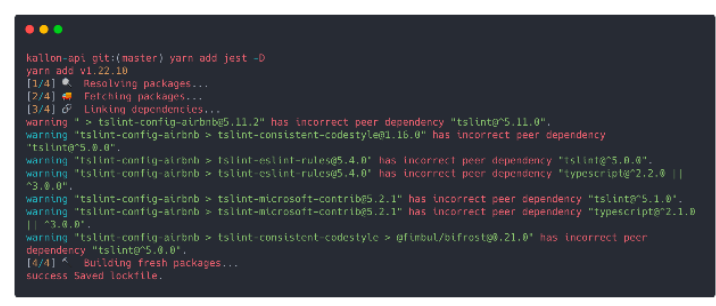

Gambar 16. Perintah untuk Install Library JEST

2. Selanjutnya tambahkan library pendukung lainnya untuk pengelolaan environment variabel. Library tersebut adalah cross-env.

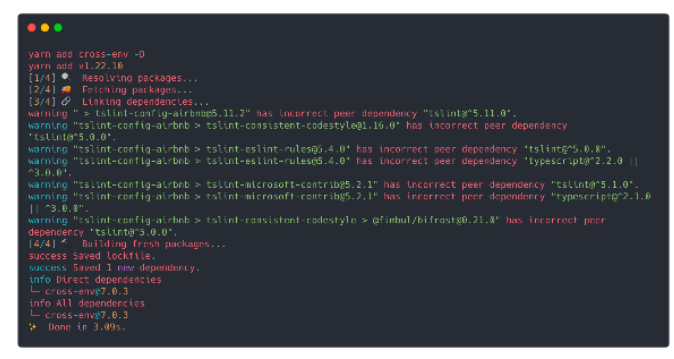

Gambar 17. Perintah untuk install library cross-env

3. Selanjutnya, modifikasi file package.json pada bagian script. Modifikasi dilakukan untuk penambahan perintah-perintah pengujian unit.



Gambar 18. Konfigurasi Perintah Pengujian pada package.json

Perintah test digunakan untuk pengujian unit pada setiap file pengujian. Perintah test:coverage digunakan untuk pengujian unit dengan tambahan informasi lingkup pengujian. Perintah test:watch digunakan untuk pengujian unit dengan pemantauan setiap ubahan pada file pengujian. Pada JEST, file pengujian di identifikasi dengan nama file yang telah ditentukan. Nama file tersebut mempunyai format sebagai berikut

\section{[nama-pengujian].test.ts}

Sebagai contoh, pada pengujian unit pengelolaan order, maka penamaan file pengujian menjadi order.test.ts. Selain itu, penamaan folder untuk penyimpanan file pengujian ditentukan menjadi_tests_. Pada gambar 19 ditampilkan struktur folder dan file pengujian.

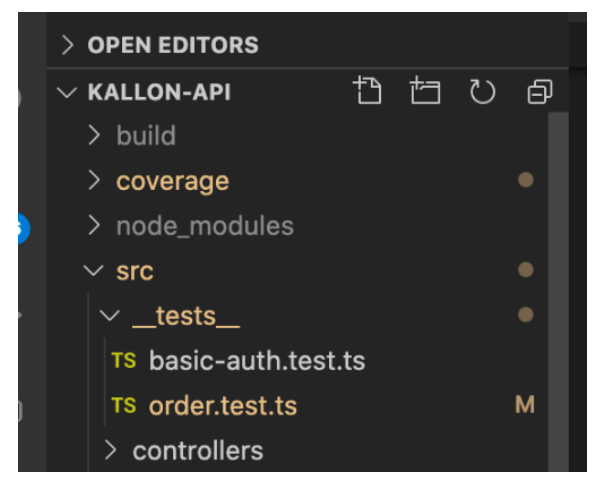

Gambar 19. Struktur Folder dan File Pengujian Unit

Hasil pengujian unit menggunakan JEST dapat dilihat secara lengkap melalui perintah test:coverage. Perintah tersebut selain menjalankan proses pengujian unit di setiap file juga menghasilkan matrik pengujian dari masing masing file uji. Matrik yang digunakan terdiri dari File, Statements, Branch, Functions, Lines dan Uncovered Lines. Matrik selain File disajikan dalam satuan persen. Matrik ini digunakan untuk mengetahui berapa banyak kode yang diuji dan mengukur apakah kode pengujian sudah cukup baik. Penjelasan tentang matriks pengujian unit terdapat pada Tabel 4. 
TABEL IV. MATRIKS PENGUJIAN UNIT

Matriks

Keterangan

\begin{tabular}{cc}
\hline File & $\begin{array}{c}\text { menunjukan file apa saja yang } \\
\text { dilibatkan dalam 1 kali eksekusi } \\
\text { pengujian unit }\end{array}$ \\
\hline Statements & $\begin{array}{c}\text { menunjukan persentase kode yang } \\
\text { dieksekusi dalam pengujian }\end{array}$ \\
\hline Branch & $\begin{array}{c}\text { menunjukan persentase struktur } \\
\text { kontrol (pengkondisian) yang } \\
\text { dieksekusi dalam pengujian }\end{array}$ \\
\hline Functions & $\begin{array}{c}\text { menunjukan persentase fungsi - } \\
\text { fungsi yang di eksekusi pada } \\
\text { pengujian }\end{array}$ \\
\hline Lines & $\begin{array}{c}\text { menunjukan persentase jumlah } \\
\text { baris yang dieksekusi dalam } \\
\text { pengujian }\end{array}$ \\
\hline Uncovered Lines & menunjukan posisi baris yang \\
& belum ter-eksekusi oleh pengujian
\end{tabular}

Pengujian unit dilakukan sesuai skenario pengujian yang terdapat pada Tabel 1. Pengujian unit dilakukan pada fitur authentikasi dan order. Unit uji untuk authentikasi terdapat pada file basicauth.test.ts. Unit uji untuk order terdapat pada file order.test.ts. Tahapan pengujian unit mengadopsi tahapan Test-First Development. Pengujian unit menggunakan JEST dapat menghasilkan laporan code coverage. Laporan ini berisi tentang persentase kode yang terlibat dalam eksekusi pengujian unit. Persentase tersebut menunjukan kualitas kode dan refactoring yang dilakukan oleh pengembangan (developer).

Tahapan pengujian menggunakan JEST hingga dihasilkan laporan code coverage dimulai dari eksekusi pengujian unit untuk authentikasi, selanjutnya pengujian unit order dan terakhir pengujian unit untuk keseluruhan fitur. Berdasarkan situs resmi dari JEST (jest.io), persentase standar dari code coverage adalah $80 \%$ (threshold). Pada penelitian ini akan ditemukan code coverage $50 \%$ pada file database.ts. File tersebut menghasilkan persentase code coverage 50\% karena tidak terdapat pengkondisian dalam kode yang ditulis. Hasil tersebut tidak mempengaruhi fungsionalitas dari kode tersebut.

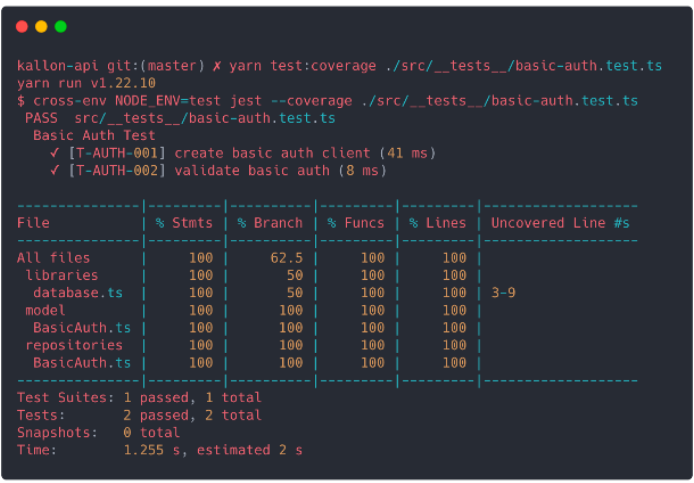

Gambar 20. Pengujian Unit pada Unit Uji Authentikasi

Pada gambar 20 ditunjukan hasil dari matriks pengujian untuk unit uji authentikasi. Hasil tersebut menunjukan nilai $100 \%$ pada Statement, Functions dan Lines. Sementara itu, pada Branch menunjukan nilai $62,5 \%$. Hasil ini bermakna bahwa eksekusi pengujian unit sudah secara menyeluruh terjadi pada kode, fungsi dan baris namun pengujian unit belum menyentuh (cover) pengkondisian secara menyeluruh.

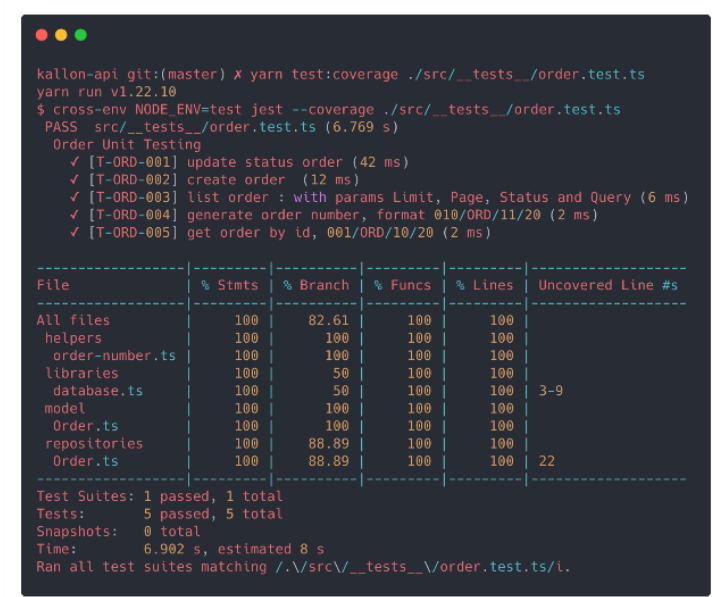

Gambar 21. Pengujian Unit pada Unit Uji Order

Pada gambar 21 ditunjukan hasil pengujian untuk unit uji order. Hasil tersebut menunjukan nilai $100 \%$ pada matriks yang sama seperti pengujian unit authentikasi. Terdapat perbedaan pada matriks Branch yaitu $82,61 \%$. Hal ini disebabkan oleh jumlah file uji yang lebih banyak dan terdapat nilai persentase Branch sebesar $88,89 \%$ pada file Order.ts. 


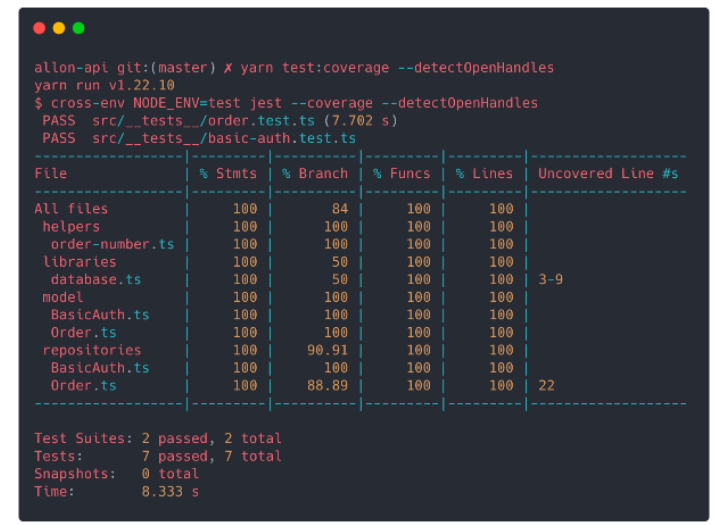

Gambar 22. Perintah Pengujian Unit untuk Unit Uji Order dan Authentikasi

Pada gambar 22 ditunjukan hasil pengujian unit pada seluruh file unit uji. Hasil tersebut menunjukan nilai $100 \%$ pada Statements, Functions dan Lines. Sementara itu, pada Branch menghasilkan $84 \%$. Nilai tersebut bermakna pengujian unit yang dijalankan sudah mengeksekusi unit uji secara menyeluruh dan dipastikan bahwa kode sudah mempunyai kualitas yang baik (lebih dari nilai threshold).

Peningkatan nilai tersebut dilalui dengan tahapan iterasi dan refactoring sesuai tahapan yang ada pada $T F D$. Iterasi pada pengujian unit meliputi penulisan kode unit uji, eksekusi pengujian dengan harapan berhasil (expected success), pengujian dengan harapan gagal (expected failed), dan refactoring.



Gambar 23. Contoh Kode Uji Unit

Pada gambar 23 ditunjukan tahapan pertama dari iterasi pengujian unit. Kode uji unit tersebut digunakan untuk pengujian requirement update status order. Fungsi untuk update status order terdapat pada OrderRepo.update(). Uji unit menggunakan fungsi assert toEqual(). Diharapkan hasil dari pengujian ini adalah setelah order dengan nomor 001/ORD/10/20 diupdate dengan status ready-to-checking maka hasil dari fungsi update() memiliki status yang sama yaitu ready-to-checking.

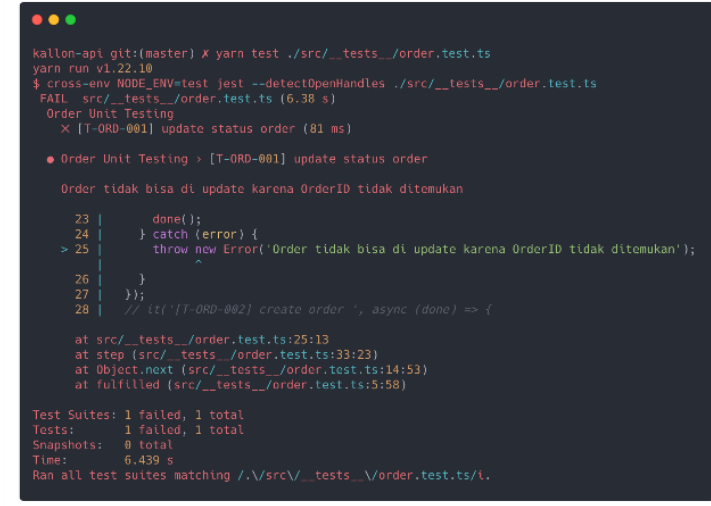

Gambar 24. Hasil Pengujian Unit T-ORD-001 Expected Failed

Pada gambar 24 ditunjukan hasil pengujian unit pada unit uji update status order. Hasil menunjukan kegagalan dikarenakan nomor order tidak ditemukan. Kemudian pada tahap ini, developer melakukan perbaikan kode uji unit. Setelah kode uji unit diperbaiki, maka dilakukan kembali ekseskusi pengujian dengan harapan berhasil.

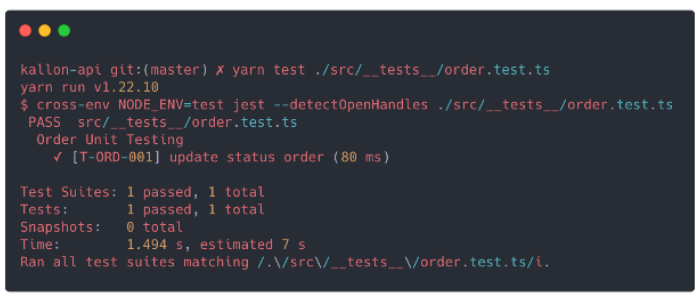

Gambar 25. Hasil Pengujian Unit T-ORD-001 Expected Success

Pada gambar 25 ditunjukan hasil pengujian unit pada unit uji update status order. Hasil menunjukan bahwa pengujian sudah berhasil. Pada tahapan ini developer akan melakukan refactoring.

\section{KESIMPULAN DAN SARAN}

Unit testing merupakan bagian dari TestDriven Development yang sangat penting. Fungsional aplikasi akan terukur dan terjaga kualitasnya mulai dari bagian terkecil (unit). Sementara itu untuk menjaga validitas fungsi terhadap requirement dari penggunanya.

Test-Driven Development dapat diterapkan pada siklus pengembangan sistem informasi yang modern. Salah satu siklus tersebut adalah Agile. Pendekatan pengujian yang dilakukan adalah TestFirst Development. Pendekatan ini melibatkan test case dan test scenario dari awal, sehingga dapat segera mengantisipasi terjadinya kesalahan baik secara lojik, bisnis maupun kode.

Metode ini memang masih mempunyai tantangan dari penerapannya. Seperti kemampuan 
pengembang untuk menentukan aspek pengujian hingga waktu pengembangan yang menjadi lebih lama. Namun, TDD dapat dijadikan seperti budaya dalam suatu projek perangkat lunak. TDD untuk waktu singkat memang memberikan dampak yang belum signifikan dalam merubah kualitas suatu perangkat lunak. Dalam jangka panjang, merupakan suatu kebiasaan yang baik, karena akan melatih pengembang dalam menyesuaikan kebutuhan sistem dengan implementasi kode, kualitas kode yang diterapkan, kualitas fungsional sistem serta dapat berdampak pada efektifitas dan efisiensi waktu projek.

\section{REFERENSI}

[1] Bott, M., \& Mesmer, B. (2019). An Analysis of Theories Supporting Agile Scrum and the Use of Scrum in Systems Engineering. Engineering Management Journal, 1-10. doi:10.1080/10429247.2019.1659701

[2] Lalband, Neelu \& Kavitha, D. (2020). Software Development Technique for the Betterment of End User Satisfaction using Agile Methodology. TEM Journal. 9. 992-1002. 10.18421/TEM93-22

[3] Khanam, Zeba \& Ahsan, M.N.. (2017). Evaluating the effectiveness of test driven development: Advantages and pitfalls. International Journal of Applied Engineering Research. 12. 7705-7716

[4] Rafique, Yahya \& Misic, Vojislav. (2013). The Effects of Test-Driven Development on External Quality and Productivity: A Meta-Analysis. Software Engineering, IEEE Transactions on. 39. 835-856. 10.1109/TSE.2012.28

[5] Besson, Felipe \& Moura, Paulo \& Kon, Fabio \& Milojicic, Dejan. (2014). Bringing Test-Driven Development to Web Service Choreographies. Journal of Systems and Software. 99. 10.1016/j.jss.2014.09.034

[6] Fucci, Davide \& Erdogmus, Hakan \& Turhan, Burak \& Oivo, Markku \& Juristo, Natalia. (2016). A Dissection of Test-Driven Development: Does It Really Matter to TestFirst or to Test-Last?. IEEE Transactions on Software Engineering. 43. 1-1. 10.1109/TSE.2016.2616877

[7] Karac, Itir \& Turhan, Burak. (2018). What Do We (Really) Know about Test-Driven Development?. IEEE Software. 35. 81-85. 10.1109/MS.2018.2801554

[8] Lalband, Neelu \& Kavitha, D. (2020). Software Development Technique for the Betterment of End User Satisfaction using Agile Methodology. TEM Journal. 9. 992-1002. 10.18421/TEM93-22
[9] Bhavsar, Krunal \& Gopalan, Samir \& Shah, Vrutik. (2020). Scrum: An Agile Process Reengineering in Software Engineering. International Journal of Innovative Technology and Exploring Engineering. 9. 10.35940/ijitee.C8545.019320.

[10] Jamaluddin, Herman Yuliansyah, Sri Winiati, Imam Riady. (2018). Implementasi Test Driven Development Pada Pengembangan Aplikasi Android Untuk Mahasiswa Universitas Ahmad Dahlan. JITEKI. Vol. 4, No. 1

[11] Myint Myint Moe. (2019). Comparative Study of TestDriven Development (TDD), Behavior-Driven Development (BDD) and Acceptance Test-Driven Development (ATDD). IJTSRD. Vol. 3, Issue 4

[12] Thohari, Afandi \& Amalia, Andika. (2018). Implementasi Test Driven Development Dalam Pengembangan Aplikasi Berbasis Web. SITECH : Jurnal Sistem Informasi dan Teknologi. 1. 1-10. 10.24176/sitech.v1i1.2255.

[13] Manuaba, Ida Bagus. (2019). Combination of Test-Driven Development and Behavior-Driven Development for Improving Backend Testing Performance. Procedia $\begin{array}{llll}\text { Computer } & \text { Science. } & \text { 79-86. }\end{array}$ 10.1016/j.procs.2019.08.144.

[14] Suzanti, Ika \& Fitriani, Nurhayati \& Jauhari, Ahmad \& Khozaimi, Ach. (2020). REST API Implementation on Android Based Monitoring Application. Journal of Physics: Conference Series. $1569.022088 .10 .1088 / 1742$ 6596/1569/2/022088

[15] Rulloh, A., Mahmudah, D., \& Kabetta, H. (2017). Implementasi REST API pada Aplikasi Panduan Kepaskibraan Berbasis Android.

[16] Perkasa, Muhammad \& Setiawan, Eko. (2018). Pembangunan Web Service Data Masyarakat Menggunakan REST API dengan Access Token. Jurnal ULTIMA Computing. 10. 19-26. 10.31937/sk.v10i1.838.

[17] Martin Fowler, Kent Beck. Refactoring Improving the Design of Existing Code Second Edition. Addison-Wesley. 2019: $57-58$

[18] Vladimir Khorikov. Unit Testing Principles, Practices, and Patterns. Manning. 2020: $64-65$

[19] Agile Data, "Introdoction to Test Driven Development", 2020

[20] Alsaqqa, Samar \& Sawalha, Samer \& Abdel-Nabi, Hiba. (2020). Agile Software Development: Methodologies and Trends. International Journal of Interactive Mobile Technologies (iJIM). 14. 246. 10.3991/ijim.v14i11.13269.

[21] Dookhun, Avishek \& Nagowah, Leckraj. (2019). Assessing The Effectiveness Of Test-Driven Development and Behavior-Driven Development in an Industry Setting. 365-370. 10.1109/ICCIKE47802.2019.9004328. 